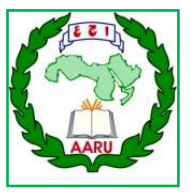

$14^{\text {th }}$ Conf. Agric. Develop. Res., Fac. of Agric., Ain Shams Univ.,

March, 2019., Cairo, Egypt

Special Issue, 27(1), 27-35, 2019

Website: http://strategy-plan.asu.edu.eg/AUJASCI/

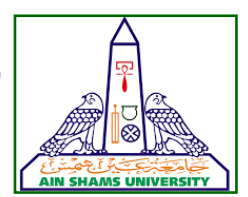

\title{
EFFECT OF MEPIQUAT CHLORIDE AND POTASSIUM SOURCES ON GROWTH AND YIELD OF PATATO PLANTS (SOLANUM TUBEROSUM L.)
}

\author{
Ali S.M.H. Abo Al-Nagaa \\ Agric. Botany Dept., Fac. of Agric., Ain Shams Univ., P.O. Box 68, Hadyek Shoubra11241, \\ Cairo, Egypt
}

*Corresponding author: aliaboalnagaa1984@gmail.com

Received 21 October, 2018,

Accepted 25 October, 2018

\begin{abstract}
In this study, Two field experiments were conducted in Ourabi operation Farm, Cairo-Ismaellia desert road at Kalubia Governorate. The experiment was carried out during the two seasons of $2013 / 2014$ and 2015/2016, to investigate the effect of plant growth regulator (Mepiquat chloride) with three different potassium fertilizers sources [chemical potassium (KC), foliar potassium (KF) and rock potassium $(\mathrm{KR})$ ] on growth development and total yield in potato plants (Solanum tuberosum L. cv. Spunta).

Chemical potassium (control) with / without Mepiquat chloride achieved better plant height, no. of stem and leaf area/plant. Rock potassium with mepiquat chloride obtained the highest productivity of fresh and dry weights, total tuber yield and yield components (weight of tubers, size of tubers, diameter of tubers and number of tubers) following by foliar potassium with mepiquat chloride compared with control treatment.
\end{abstract}

Keywords: Potato, Solanum tuberosum, Rock potassium, Mepiquat chloride, Foliar potassium, Chemical potassium.

\section{INTRODUCTION}

Potato (Solanum tuberosum L. cv. Spunta) is one of the most widely grown tuber crop in the world and contributes immensely to human nutrition and food security (Jackson, 1999). Potato has high carbohydrate and low fat content that makes it an excellent energy source for human on sumption
(Dean, 1994). Potato contains high quality proteins and a substantial amount of essential vitamins, minerals, high carbohydrate content, calcium, potassium and vitamin (Blagoeva et al 2004).

Potassium is particularly important in helping plants adapt to environmental stress such as drought, winter hardiness, tolerance to diseases, insect pests and frost damage (Brady and Weil, 2002). Moreover, It is also involved in activation of enzymes important to energy utilization, starch synthesis, $\mathrm{N}$ metabolism, and respiration. These enzymes are abundant in the meristematic tissue at the growing points (like sprouting tuber eyes) where cells are dividing and primary tissues are formed (Havlin et al 2005). $\mathrm{K}$ is an essential nutrient for all plants and has a major effect upon growth and yield of potatoes as well as the general health and vigor of the crop (Abd EL-Latif et al 2011). Potassium is an essential nutrient for growth of the crops, including potatoes. Its role is well documented in photosynthesis, increasing enzyme activity, improving synthesis of protein, carbohydrates and fats, translocation of photosynthetate resulting higher productivity of potato tubers (Daniel et al 2016)

Mepiquat chloride appears to be acting as an anti-plant growth hormone agent to stunt growth through some reaction or interference with the effects of plant growth hormones. Thus enhances early plant growth by adding growth regulating agents to the soil around the seeds and/or to the plant during its vegetative growth period to compensate for the interference later in the cycle by mepiquat chloride, and applying mepiquat chloride to the plant at a rate sufficient to stunt vegetative 
growth. This combination of steps enhances early plant growth and plant mass (particularly root and stem growth) which translates into enhanced set and retention. Thereafter, further vegetative growth is retarded by mepiquat chloride in favor of potato (tubers) production, because the plant growth was accelerated early in the life cycle, however, the plant assimilates larger quantities of nutrients which provides the plant immune system with a higher level of ability to resist diseases, recover from insect attack, and endure drought conditions (Clark et al 1998). However, Prakash et al (2001) investigated the effect of growth retardant (mepiquat chloride at 500 and $1000 \mathrm{ppm}$ ) on growth parameters and tuber yield in potato cultivars Kufri Chandrmukhi and HPS-II/67. Leaf area decreased by growth retardant treatment. An increase in the concentration of growth retardant resulted in an increase in specific leaf weight (SLW). Moreover, Vyakarnahal et al (2010) studied the effect of growth retardant and methods of application on growth and yield of potato crop in cultivar Kufri Pukhraj. Mepiquat Chloride at 100 ppm along with the control were used with four application methods viz., tuber dipping, foliar spray at 30 days after planting, foliar spray at 45 days after planting, foliar spray at 30 and 45 days after planting and a control treatment. Mepiquat chloride improved establishment and growth parameters (plant height, number of stems, leaf area and total dry weight). Mepiquat chloride $100 \mathrm{ppm}$ foliar sprayed at 30 and 45 days after planting proved to be the most effective. The tubers yield under this treatment was significantly superior over the control (water dip). This suggested that mapiquat chloride $100 \mathrm{ppm}$ foliar sprayed at 30 and 45 days after planting helped best in obtaining the higher growth, yield and quality parameters.

The current investigation was designed to assess the response of potato plants to growth regulators and potassium sources treatments and its relation to tubers quality and yield productivity.

\section{MATERIAL AND METHODS}

Two field experiments were conducted in Ourabi operation, Cairo-Ismaellia desert road at Kalubia Governorate. The experiment was carried out during the two seasons of 2013/2014 and 2015/2016 (Winter season) to investigate the effect of plant growth regulator (Mepiquat chloride) with three different potassium fertilizers sources on growth, development, total yield in potato plants (Solanum tuberosum L. cv. Spunta) .

Experimental design was carried out in a split plot design with four replicates. Where the three different potassium fertilizers sources were located in the main plots and the plant growth regulator was randomly distributed in the sub plots. Each plot size was kept at $6 \times 7 \mathrm{~m}$ with eight rows of 0.75 meters in width and 7 meters in length.

Physical and chemical properties of the experimental soil were made before sowing, in Central Lab., Faculty of Agric., Ain Shams Univ. are presented in Table (1-2).

Table 1. Physical and chemical analysis of the experimental Soil .

\begin{tabular}{|c|c|c|c|c|c|c|c|c|c|c|c|c|}
\hline \multicolumn{6}{|c|}{ Mechanical analysis } & \multicolumn{7}{|c|}{ Saturation soluble extract } \\
\hline \multicolumn{4}{|c|}{ Particle size distribution } & \multirow[t]{2}{*}{$\mathrm{pH}$} & \multirow[t]{2}{*}{$\mathrm{CaCO}_{3} \%$} & \multirow[t]{2}{*}{$\begin{array}{c}\text { E.C } \\
\text { ds/m }\end{array}$} & \multicolumn{3}{|c|}{$\begin{array}{c}\text { Soluble anions } \\
(\mathrm{meq} / \mathrm{I})\end{array}$} & \multicolumn{3}{|c|}{$\begin{array}{c}\text { Soluble cations } \\
(\mathrm{ppm})\end{array}$} \\
\hline Clay & Silt & Sand & $\begin{array}{c}\text { Soil } \\
\text { texture }\end{array}$ & & & & $\mathrm{HCO}_{3}^{-}$ & $\mathrm{Cl}$ & $\mathrm{SO}_{4}^{-}$ & $\mathbf{K}^{+}$ & $\mathrm{Mg}^{++}$ & $\mathrm{Na}^{+}$ \\
\hline $2 \%$ & $3 \%$ & $95 \%$ & Sandy & 7.31 & 3 & 0.36 & 0.6 & 1.6 & 1.4 & 0.15 & 0.24 & 0.21 \\
\hline
\end{tabular}

Table 2. Chemical properties of water using in the experimental farm of Ourabi operation.

\begin{tabular}{|c|c|c|c|c|c|c|c|c|c|}
\hline \multirow{3}{*}{$\mathrm{pH}$} & \multirow{3}{*}{$\begin{array}{c}\text { E.C } \\
\text { ds/m }\end{array}$} & \multicolumn{8}{|c|}{ Saturation soluble extract } \\
\hline & & \multicolumn{4}{|c|}{ Soluble anions (meq / I) } & \multicolumn{4}{|c|}{ Soluble cations ( meq / I ) } \\
\hline & & $\mathrm{HCO}_{3-}^{-}$ & $\mathrm{CO}_{3}^{-}$ & $\mathrm{SO}_{4}^{-}$ & $\mathrm{Cl}^{-}$ & $\mathrm{Ca}^{2+}$ & $\mathrm{Mg}^{++}$ & $\mathrm{Na}^{+}$ & $\mathrm{K}^{+}$ \\
\hline 8.07 & 0.54 & 1 & n.d & 1 & 3.4 & 2.1 & 2.5 & 0.5 & 0.3 \\
\hline
\end{tabular}


Rock potassium (KR) (Natural fertilizer contained $70.65 \% \mathrm{SiO}_{2}$ and $10.1 \% \mathrm{~K}_{2} \mathrm{O}$, produced by Al-Ahram Company $300 \mathrm{~kg} /$ fed at once during soil preparation for planting. Chemical potassium (KC) $200 \mathrm{~kg} /$ fed. Potassium fertilizer (potassium sulphate) was added on two installments at the age of 50 and 70 days from the date of sowing. Foliar potassium (KF) (commercial fertilizer contained $60 \% \mathrm{~K}_{2} \mathrm{O}$, produced by Union Company) . (1 $\mathrm{g} / \mathrm{I})$ was sprayed three times at 45,60 and 75 days after sowing. Mepiquat chloride (MC) 150 ppm spraying was carried out twice for each at four and six weeks after sowing using hand operated compressed air sprayers, while the control plants were sprayed with distilled water. ["Triton B" was used as a wetting agent at the rate of $0.10 \%$ ].

Each treatment was collected in every season at 50, 85 and 120 days after sowing. Four plants from each treatment were taken randomly at 50 and 85 days to determine plant height $(\mathrm{cm})$, number of branches per plant, fresh and dry weights of shoot ( $\mathrm{g} /$ plant), number of tubers per plant, weight of tubers ( $\mathrm{g} /$ plant $)$, diameter of tubers $(\mathrm{mm})$ and size of tubers $(\mathrm{ml})$.In addition to leaf area $\left(\mathrm{cm}^{2} /\right.$ plant $)$ in the $2^{\text {nd }}$ sample, using an Area meter (II.3000 portable area meter Lin Coin, Nebraska 68504 USA). Tubers were harvested 120 days after planting. At harvest tubers from each treatment were rinsed free of soil and the following measurements were made: number of tubers/plant, weight of tubers ( $\mathrm{g} /$ plant), diameter of tubers $(\mathrm{mm})$, size of tubers (ml), total tuber yield (ten/fed).

Statistical analysis of the previous characters was made as described by Steel and Torrie (1960) and Duncan's new multiple ranges were used to differentiate between means as described by Duncan (1955).

\section{RESULTS AND DISCUSSION}

\section{Plant height}

The effect of different treatments on potato plant height is presented in (Table 3). As for the two seasons potassium sulphate or without mepiquat chloride significant increase in potato plant height as compared to the other treatments after 85 days from sowing. Our results on the effect of mepiquat chloride are in agreement with findings of those obtained from Hassan et al (1989), Prakash et al (1999) and Jayakumar et al (2001). Mepiquat chloride reduced plant height significantly compared to the control, which recorded the greatest plant height of potato.

In regard to the effect of interaction on plant height, data tabulated in Table (3) showed that the highest value was recorded for potassium sulphate and without mepiquat chloride after 85 days from sowing in the two tested seasons. On the other hand, the lowest value was obtained from the interaction between foliar potassium and mepiquat chloride in both seasons.

\section{Number of branches/plant}

Results in Table (3) illustrated that potassium sulphate (control) and potassium rock significantly increased in number of branches/plant than the application of the same fertilizer with growth retardant which reached the same level of significance in both samples. While, without mepiquat treatment obtained significant increment compared with mepiquat treatment after 85 days from sowing. Obtained results on mepiquat are agreement with those reported by Hassan et al (1989) on potato.

As regard for the interaction, data in Table (3) indicate that the application of potassium sulphate or potassium rock both of with without mepiquat treatments recorded significant increment compared with the other treatments in both seasons.

\section{Fresh and dry weights}

Data in Table (4) revealed the effect of different treatments on fresh and dry weights of shoot system. Shoot fresh and dry weights of potato plants tended to increase with advancement of age in both seasons. The treatments of potassium sources effect, spraying of potassium foliar or the application of potassium rock increased significantly both fresh and dry weights against the control (KC). This increase in fresh weight reached (25 to $46.87 \mathrm{~g} /$ plant) and in dry weights (3.5 to 6.3 $\mathrm{g} /$ plant) for the first and second samples respectively. In this connection, spraying of mepiquat chloride had positive effects on fresh and dry weights of potato shoot after 85 days from sowing. . Potassium is an essential plant nutrient that plays a very important role in plant growth and development. Similar results were obtained with White et al (2005) and Vyakarnahal et al (2010) on potato.

Results in Table (4) showed that the best combination that gave the highest value of fresh and dry weights of shoots appeared to be that involving all potassium sources with mepiquat treatments compared with the other treatments. 
Table 3. Effect of chemical potassium (KC), foliar potassium ( KF ), rock potassium (KR) and growth retardant (mepiquat chloride) applications on potato plant height $(\mathrm{cm})$ and number of branches/plant during the two sampling dates in both seasons.

\begin{tabular}{|c|c|c|c|c|c|c|c|c|c|c|c|c|c|}
\hline \multirow{3}{*}{$\begin{array}{c}\text { Sampling } \\
\text { dates }\end{array}$} & \multicolumn{7}{|c|}{ Plant height $(\mathrm{cm})$} & \multicolumn{6}{|c|}{ Number of branches /plant } \\
\hline & \multicolumn{4}{|c|}{$1^{\text {st }}$ season } & \multicolumn{3}{|c|}{$2^{\text {nd }}$ season } & \multicolumn{3}{|c|}{$1^{\text {st }}$ season } & \multicolumn{3}{|c|}{$2^{\text {nd }}$ season } \\
\hline & Treatments & 0 & $\begin{array}{r}\text { MC } \\
150 \\
\mathrm{ppm} \\
\end{array}$ & $\begin{array}{c}\text { Mean } \\
\mathrm{K} \\
\text { ferti. }\end{array}$ & 0 & $\begin{array}{l}\text { MC } \\
150 \\
\mathrm{ppm}\end{array}$ & $\begin{array}{c}\text { Mean } \\
K \\
\text { ferti. }\end{array}$ & 0 & $\begin{array}{r}\text { MC } \\
150 \\
\text { ppm } \\
\end{array}$ & $\begin{array}{l}\text { Mean } \\
\text { K ferti. }\end{array}$ & 0 & $\begin{array}{r}\text { MC } \\
150 \\
\text { ppm }\end{array}$ & $\begin{array}{l}\text { Mean } \\
K \text { ferti. }\end{array}$ \\
\hline $1^{\text {st }}$ & KC & $30.50^{d}$ & $24.88^{f}$ & $27.69^{d}$ & $31.00^{d}$ & $25.00^{\mathrm{g}}$ & $28.00^{d}$ & $11.75^{\mathrm{a}}$ & $9.75^{\text {edf }}$ & $10.75^{\mathrm{a}}$ & $12.00^{\mathrm{a}}$ & $10.00^{\text {dce }}$ & $11.00^{a}$ \\
\hline Sample & KF & $24.13^{f}$ & $20.88^{g}$ & $22.50^{f}$ & $24.63^{9}$ & $21.00^{\mathrm{h}}$ & $22.81^{f}$ & $10.50^{\mathrm{bdc}}$ & $9.00^{\dagger}$ & $9.75^{b}$ & $10.75^{\mathrm{bc}}$ & $9.250^{\mathrm{e}}$ & $10.00^{b}$ \\
\hline \multirow[t]{2}{*}{50 DAS } & KR & $27.38^{\mathrm{e}}$ & $22.00^{9}$ & $24.69^{\mathrm{e}}$ & $27.88^{\mathrm{e}}$ & $22.25^{\mathrm{h}}$ & $25.06^{e}$ & $11.50^{\mathrm{ba}}$ & $9.50^{\text {edf }}$ & $10.5^{\text {ba }}$ & $11.75^{\mathrm{a}}$ & $9.750^{\text {de }}$ & $10.75^{\mathrm{a}}$ \\
\hline & Mean GR & $27.33^{b}$ & $22.58^{\mathrm{C}}$ & $\overline{-}$ & $27.83^{b}$ & $22.75^{\mathrm{c}}$ & 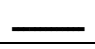 & $11.25^{\mathrm{a}}$ & $9.42^{b}$ & — & $11.50^{\mathrm{a}}$ & $9.67^{b}$ & \\
\hline \multirow{4}{*}{$\begin{array}{c}2^{\text {nd }} \\
\text { Sample } \\
85 \text { DAS }\end{array}$} & KC & $40.50^{\mathrm{a}}$ & $30.00^{d}$ & $35.25^{\mathrm{a}}$ & $41.00^{\mathrm{a}}$ & $30.25^{d}$ & $35.63^{\mathrm{a}}$ & $11.50^{\mathrm{ba}}$ & $10.25^{\text {edc }}$ & $10.875^{a}$ & $11.75^{\mathrm{a}}$ & $10.50^{d c}$ & $11.13^{\mathrm{a}}$ \\
\hline & KF & $34.13^{c}$ & $25.88^{\mathrm{fe}}$ & $30.00^{c}$ & $34.50^{c}$ & $26.00^{\mathrm{fg}}$ & $30.25^{c}$ & $10.25^{\mathrm{edc}}$ & $9.25^{\mathrm{ef}}$ & $9.75^{b}$ & $10.50^{d c}$ & $9.50^{\mathrm{e}}$ & $10.00^{b}$ \\
\hline & KR & $37.38^{\mathrm{b}}$ & $27.00^{\mathrm{e}}$ & $32.19^{b}$ & $38.00^{\mathrm{b}}$ & $27.25^{\mathrm{fe}}$ & $32.63^{b}$ & $11.25^{\mathrm{bac}}$ & $9.25^{\mathrm{ef}}$ & $10.25^{\mathrm{ba}}$ & $11.50^{\mathrm{ba}}$ & $9.50^{\mathrm{e}}$ & $10.50^{\mathrm{ba}}$ \\
\hline & Mean GR & $37.33^{a}$ & $27.63^{b}$ & 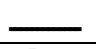 & $37.83^{a}$ & $27.83^{b}$ & - & $11.00^{\mathrm{a}}$ & $9.58^{\mathrm{b}}$ & - & $11.25^{\mathrm{a}}$ & $9.83^{b}$ & 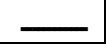 \\
\hline $\begin{array}{l}\text { GR=Grow } \\
M C=\text { Mep } \\
\text { Ferti = fert }\end{array}$ & $\begin{array}{l}\text { h retardant } \\
\text { quat chloride } \\
\text { izer }\end{array}$ & & & - - Dea & $\begin{array}{l}\text { Is with } \mathrm{t} \\
=\text { day aft }\end{array}$ & $\begin{array}{l}\text { he same } \\
\text { er sowin }\end{array}$ & $\begin{array}{l}\text { e lette } \\
\text { ng }\end{array}$ & וd & . & प्र & rtilizorc & 0.05 & \\
\hline
\end{tabular}

Table 4. Effect of chemical potassium (KC), foliar potassium ( KF ), rock potassium (KR) and growth retardant (mepiquat chloride) applications on fresh weight (g/plant) and dry weight ( $\mathrm{g}$ /plant) of potato shoot during the two sampling dates in both seasons.

\begin{tabular}{|c|c|c|c|c|c|c|c|c|c|c|c|c|c|}
\hline \multirow[b]{3}{*}{$\begin{array}{c}\text { Sampling } \\
\text { dates }\end{array}$} & \multicolumn{7}{|c|}{ Fresh weight (g /plant) } & \multicolumn{6}{|c|}{ Dry weight (g /plant) } \\
\hline & \multicolumn{4}{|c|}{$1^{\text {st }}$ season } & \multicolumn{3}{|c|}{$2^{\text {nd }}$ season } & \multicolumn{3}{|c|}{$1^{\text {st }}$ season } & \multicolumn{3}{|c|}{$2^{\text {nd }}$ season } \\
\hline & Treatments & 0 & $\begin{array}{c}\text { MC } \\
150 \\
\text { ppm }\end{array}$ & $\begin{array}{l}\text { Mean } \\
K \text { ferti. }\end{array}$ & 0 & $\begin{array}{c}\text { MC } \\
150 \\
\text { ppm }\end{array}$ & $\begin{array}{l}\text { Mean } \\
\text { K ferti. }\end{array}$ & 0 & $\begin{array}{c}\text { MC } \\
150 \\
\text { ppm }\end{array}$ & $\begin{array}{l}\text { Mean } \\
\text { K ferti. }\end{array}$ & 0 & $\begin{array}{r}\text { MC } \\
150 \\
\text { ppm } \\
\end{array}$ & $\begin{array}{l}\text { Mean } \\
K \text { ferti. }\end{array}$ \\
\hline \multirow{4}{*}{$\begin{array}{c}1^{\text {st }} \\
\text { Sample } \\
50 \text { DAS }\end{array}$} & $\mathrm{KC}$ & $25.00^{\mathrm{e}}$ & $33.00^{c}$ & $29.00^{d}$ & $28.0^{\mathrm{e}}$ & $36.00^{c}$ & $32.00^{d}$ & $3.53^{f}$ & $4.77^{\mathrm{cd}}$ & $4.15^{\mathrm{e}}$ & $3.95^{\mathrm{e}}$ & $5.21^{\mathrm{c}}$ & $4.58^{\mathrm{e}}$ \\
\hline & KF & $29.00^{d}$ & $34.50^{c}$ & $31.75^{c}$ & $32.0^{d}$ & $37.50^{c}$ & $34.75^{c}$ & $4.18^{\mathrm{e}}$ & $4.82^{c d}$ & $4.50^{d}$ & $4.63^{d}$ & $5.27^{c}$ & $4.95^{\mathrm{d}}$ \\
\hline & KR & $30.00^{d}$ & $34.88^{\mathrm{C}}$ & $32.438^{c}$ & $33.0^{d}$ & $37.88^{\mathrm{c}}$ & $35.44^{\mathrm{c}}$ & $4.66^{d}$ & $5.08^{\mathrm{cbd}}$ & $4.87^{c}$ & $5.17^{\mathrm{c}}$ & $5.56^{\mathrm{cb}}$ & $5.36^{\mathrm{C}}$ \\
\hline & Mean GR & $28.00^{d}$ & $34.13^{\mathrm{c}}$ & $\longrightarrow$ & $31.00^{d}$ & $37.13^{c}$ & - & $4.12^{d}$ & $4.89^{c}$ & & $4.58^{c}$ & $5.35^{\mathrm{b}}$ & \\
\hline \multirow{4}{*}{$\begin{array}{c}2^{\text {nd }} \\
\text { Sample } \\
85 \text { DAS }\end{array}$} & KC & $34.00^{\mathrm{C}}$ & $42.00^{\mathrm{a}}$ & $38.00^{b}$ & $37.00^{c}$ & $45.25^{\mathrm{a}}$ & $41.13^{b}$ & $4.80^{\mathrm{cd}}$ & $6.08^{\mathrm{a}}$ & $5.44^{\mathrm{b}}$ & $5.22^{\mathrm{C}}$ & $6.55^{\mathrm{a}}$ & $5.88^{b}$ \\
\hline & KF & $38.00^{\mathrm{b}}$ & $43.50^{a}$ & $40.75^{a}$ & $41.00^{b}$ & $46.50^{\mathrm{a}}$ & $43.75^{a}$ & $5.14^{\mathrm{cb}}$ & $6.06^{a}$ & $5.60^{b}$ & $5.50^{\mathrm{cb}}$ & $6.53^{\mathrm{a}}$ & $6.02^{b}$ \\
\hline & KR & $39.00^{\mathrm{b}}$ & $43.88^{\mathrm{a}}$ & $41.44^{\mathrm{a}}$ & $42.00^{\mathrm{b}}$ & $46.875^{\mathrm{a}}$ & $44.44^{\mathrm{a}}$ & $5.48^{\mathrm{b}}$ & $6.39^{\mathrm{a}}$ & $5.93^{\mathrm{a}}$ & $5.91^{\mathrm{b}}$ & $6.83^{\mathrm{a}}$ & $6.36^{\mathrm{a}}$ \\
\hline & Mean GR & $37.33^{b}$ & $43.13^{a}$ & 工 & $37.83^{b}$ & $46.21^{a}$ & 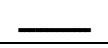 & $5.14^{b}$ & $6.18^{a}$ & & $5.54^{\mathrm{b}}$ & $6.64^{\mathrm{a}}$ & \\
\hline \multirow{2}{*}{\multicolumn{3}{|c|}{$\begin{array}{l}\text { GR=Growth retardant } \\
M C=\text { Mepiquat chloride } \\
\text { Ferti = fertilizer }\end{array}$}} & & -Duncé & & & & $=D^{2}$ & means & & & & \\
\hline & & & & $\begin{array}{l}\text {-Means } \\
-D A S=d\end{array}$ & $\begin{array}{l}\text { with the } \\
\text { day after }\end{array}$ & $\begin{array}{l}\text { same let } \\
\text { sowing }\end{array}$ & etter a & $n$ & & differe & at $p<0$. & & \\
\hline
\end{tabular}

\section{Leaf area}

Data presented in Table (5) revealed the effect of different treatments on leaf area of potato plant after 85 days from sowing in both seasons. The leaf area in the $2^{\text {nd }}$ season run parallel to the detected in the $1^{\text {st }}$ season with the same level of sig- nificance in the $2^{\text {nd }}$ sampling data. Application of potassium chemical had significant effect on leaf area. On the other hand, the best treatment was detected with without mepiquat chloride treatment. Decreased in leaf area by growth under spraying of mepiquat was observed by Prakash et al (2001) on potato. 
Concerning the interaction between potassium sources and growth regulator treatment data in Table (5) showed that the best combination was detected with spraying of mepiquat chloride with application of potassium sulphate fertilization recorded significant increment in leaf area are against the application of mepiquat chloride with the other potassium fertilizers.

Table 5. Effect of chemical potassium (KC), foliar potassium ( $\mathrm{KF}$ ), rock potassium (KR) and growth retardant (Mepiquat chloride) applications on leaf area $\left(\mathrm{cm}^{2} /\right.$ plant) of potato plants in the $2^{\text {nd }}$ sample in both seasons.

\begin{tabular}{|c|c|c|c|c|c|c|c|}
\hline \multirow{2}{*}{$\begin{array}{c}\text { Sampling } \\
\text { dates }\end{array}$} & \multicolumn{4}{|c|}{$1^{\text {st }}$ season } & \multicolumn{3}{|c|}{$2^{\text {nd }}$ season } \\
\hline & Treatments & 0 & $\begin{array}{c}\text { MC } \\
150 \text { ppm }\end{array}$ & Mean $\mathrm{K}$ ferti. & 0 & $\begin{array}{c}\text { MC } \\
150 \text { ppm }\end{array}$ & $\begin{array}{c}\text { Mean K } \\
\text { ferti. }\end{array}$ \\
\hline \multirow{4}{*}{$\begin{array}{c}2^{\text {nd }} \\
\text { Sample } \\
85 \text { DAS }\end{array}$} & $\mathrm{KC}$ & $39.00^{a}$ & $29.00^{c}$ & $34.00^{a}$ & $39.80^{a}$ & $29.80^{C}$ & $34.80^{\mathrm{a}}$ \\
\hline & KF & $37.50^{\text {ba }}$ & $25.50^{d}$ & $31.50^{b}$ & $38.43^{\mathrm{ba}}$ & $26.30^{d}$ & $32.36^{b}$ \\
\hline & KR & $36.00^{\mathrm{b}}$ & $23.30^{d}$ & $29.65^{c}$ & $36.80^{\mathrm{b}}$ & $24.10^{d}$ & $30.45^{c}$ \\
\hline & Mean GR & $37.50^{\mathrm{a}}$ & $25.93^{b}$ & 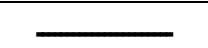 & $38.34^{\mathrm{a}}$ & $26.73^{b}$ & - \\
\hline
\end{tabular}

$\mathrm{GR}=$ Growth retardants

-Duncan within sampling date, means of $\mathrm{GR}$ and means of $\mathrm{K}$ fertilizers.

$\mathrm{MC}=$ Mepiquat chloride

Ferti $=$ fertilizer

-Means with the same letter are not significantly different at $p>0.05$.

-DAS=day after sowing

\section{Tubers number/plant}

In respect to the effect of potassium sources, data in Table (6) show that there were no significant differences in potassium sources on number of potato tubers/plant during the three sampling dates of the two seasons. On the other hand, spraying of mepiquat chloride at $150 \mathrm{ppm}$ obtained significant increase on number of potato tubers/plant compared with control treatment. Similar results were obtained with Hassan et al (1989); Birbal and Kushwah (2003).

It clear from results in Table (6) that the best treatments combination were potassium sources with spraying of mepiquat chloride treatment in all growth periods in both seasons.

\section{Potato tuber weight}

Data of potato tubers weight /plant during the three sampling dates in both seasons are presented in Table (6). Weight of tubers (g/plant) gently increased significantly (especially with GRs) with advancement of plant age (50, 85 and 120 days). The highest value of mean of potato tuber weight was obtained from application of potassium rock after 120 days from sowing in both seasons following by potassium foliar treatment compared with the other treatments. However, spraying of mepiquat chloride gave significant increment on mean of potato tuber weight after 120 days from sowing in two seasons. Similar results were obtained with Tsegaw et al.(2005) who showed that mepiquat chloride (MC) used in crop field management with many purposes including potato quality.

Data listed in Table (6) show that the highest value of mean of potato tuber weight appeared to be that involving potassium rock treatment with spraying of mepiquat chloride following by potassium foliar with mepiquat chloride after 120 days from sowing in both seasons.

\section{Tuber diameter}

Data presented in Table (7) illustrated the effect of three potassium sources on tuber diameter during three sampling dates in both seasons. It is clear that significant increase in tubers diameter was achieved by the application of potassium rock and potassium foliar fertilization after 120 days. However, mepiquat chloride had superior tuber diameter after 120 days from sowing in both seasons.

Regarding the interaction effect, data in Table (7) indicated that the application of potassium rock and potassium foliar with mepiquat chloride gave the highest value of tubers diameter after 120 days from sowing in both seasons.

\section{Tuber size}

Table (7) revealed the effect of different treatments on potato tuber size during the three sampling dates in both seasons. It is clear that the size of tubers increased with advancement of plant age (50, 85 and 120 days). 
Table 6. Effect of chemical potassium (KC), foliar potassium (KF), rock potassium (KR) and growth retardant (mepiquat chloride) applications on number of potato tubers/plant and mean of potato tuber weight (g)/plant during the two sampling dates in both seasons.

\begin{tabular}{|c|c|c|c|c|c|c|c|c|c|c|c|c|c|}
\hline \multirow{3}{*}{$\begin{array}{c}\text { Sampling } \\
\text { dates }\end{array}$} & \multicolumn{7}{|c|}{ Number of potato tubers/plant } & \multicolumn{6}{|c|}{ Mean of potato tuber weight $(\mathrm{g}) / \mathrm{plant}$} \\
\hline & \multicolumn{4}{|c|}{$1^{\text {st }}$ season } & \multicolumn{3}{|c|}{$2^{\text {nd }}$ season } & \multicolumn{3}{|c|}{$1^{\text {st }}$ season } & \multicolumn{3}{|c|}{$2^{\text {nd }}$ season } \\
\hline & Treatments & 0 & $\begin{array}{l}\text { MC } \\
150 \\
\mathrm{ppm} \\
\end{array}$ & $\begin{array}{l}\text { Mean } \\
\text { K ferti. }\end{array}$ & 0 & $\begin{array}{c}\text { MC } \\
150 \\
\text { ppm } \\
\end{array}$ & $\begin{array}{c}\text { Mean } \\
\text { K ferti. }\end{array}$ & 0 & $\begin{array}{c}\text { MC } \\
150 \\
\text { ppm }\end{array}$ & $\begin{array}{c}\text { Mean } \\
\text { K ferti. }\end{array}$ & 0 & $\begin{array}{c}\text { MC } \\
150 \\
\text { ppm }\end{array}$ & $\begin{array}{l}\text { Mean } \\
\text { K ferti. }\end{array}$ \\
\hline $1^{\text {st }}$ & KC & $0^{c}$ & $5^{\mathrm{a}}$ & $2.5^{\mathrm{b}}$ & $0^{c}$ & $5^{\mathrm{a}}$ & $2.5^{\mathrm{b}}$ & $0.000^{i}$ & $110.0^{\mathrm{gh}}$ & $55.00^{g}$ & $0.000^{i}$ & $115.5^{\mathrm{gh}}$ & $57.75^{\mathrm{e}}$ \\
\hline Sample & KF & $4^{\mathrm{b}}$ & $5^{\mathrm{a}}$ & $4.5^{\mathrm{a}}$ & $4^{\mathrm{b}}$ & $5^{\mathrm{a}}$ & $4.5^{\mathrm{a}}$ & $70.20^{\mathrm{h}}$ & $112.6^{\mathrm{gh}}$ & $91.40^{\mathrm{fg}}$ & $75.20^{\mathrm{h}}$ & $117.8^{\mathrm{gh}}$ & $96.50^{\mathrm{de}}$ \\
\hline \multirow[t]{2}{*}{50 DAS } & KR & $4^{\mathrm{b}}$ & $5^{\mathrm{a}}$ & $4.5^{\mathrm{a}}$ & $4^{\mathrm{b}}$ & $5^{\mathrm{a}}$ & $4.5^{\mathrm{a}}$ & $102.0^{\text {gh }}$ & $120.0^{\mathrm{fgh}}$ & $111.0^{\mathrm{fe}}$ & $107.3^{g h}$ & $125.0^{\mathrm{fgh}}$ & $116.1^{\text {de }}$ \\
\hline & Mean GR & $2.67^{\mathrm{c}}$ & $5^{\mathrm{a}}$ & - & $2.67^{c}$ & $5^{\mathrm{a}}$ & & $57.40^{\mathrm{e}}$ & $114.2^{d}$ & & $60.80^{\mathrm{e}}$ & $119.4^{d}$ & \\
\hline \multirow{4}{*}{$\begin{array}{c}2^{\text {nd }} \\
\text { Sample } \\
85 \text { DAS }\end{array}$} & KC & $4^{b}$ & $5^{\mathrm{a}}$ & $4.5^{\mathrm{a}}$ & $4^{b}$ & $5^{a}$ & $4.5^{\mathrm{a}}$ & $97.90^{\mathrm{h}}$ & $202.5^{\text {ecd }}$ & $150.2^{\text {de }}$ & $102.9^{h}$ & $208.0^{\text {ecd }}$ & $155.5^{\mathrm{dc}}$ \\
\hline & KF & $4^{b}$ & $5^{\mathrm{a}}$ & $4.5^{\mathrm{a}}$ & $4^{b}$ & $5^{\mathrm{a}}$ & $4.5^{\mathrm{a}}$ & $180.9^{\text {efgd }}$ & $220.3^{\mathrm{bcd}}$ & $200.6^{d c}$ & $185.9^{\text {efgd }}$ & $225.3^{\mathrm{bcd}}$ & $205.6^{b c}$ \\
\hline & KR & $4^{b}$ & $5^{\mathrm{a}}$ & $4.5^{\mathrm{a}}$ & $4^{b}$ & $5^{\mathrm{a}}$ & $4.5^{\mathrm{a}}$ & $197.8^{\text {efcd }}$ & $269.1^{\mathrm{bc}}$ & $233.4^{\mathrm{bc}}$ & $202.8^{\text {efcd }}$ & $274.1^{\mathrm{bc}}$ & $238.4^{\text {ba }}$ \\
\hline & Mean GR & $4^{b}$ & $5^{\mathrm{a}}$ & 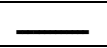 & $4^{b}$ & $5^{\mathrm{a}}$ & 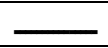 & $158.9^{c}$ & $230.6^{\mathrm{b}}$ & - & $163.8^{\mathrm{c}}$ & $235.8^{\mathrm{b}}$ & \\
\hline \multirow{4}{*}{$\begin{array}{c}\text { 3rd } \\
\text { Sample } \\
120 \text { DAS }\end{array}$} & KC & $4^{b}$ & $5^{\mathrm{a}}$ & $4.5^{\mathrm{a}}$ & $4^{b}$ & $5^{a}$ & $4.5^{\mathrm{a}}$ & $138.1^{\text {efgh }}$ & $270.0^{\mathrm{bc}}$ & $204.1^{c}$ & $142.0^{\text {efgh }}$ & $275.0^{\text {bc }}$ & $208.5^{b c}$ \\
\hline & KF & $4^{b}$ & $5^{\mathrm{a}}$ & $4.5^{\mathrm{a}}$ & $4^{b}$ & $5^{a}$ & $4.5^{\mathrm{a}}$ & $243.8^{\mathrm{bcd}}$ & $293.8^{\text {ba }}$ & $268.8^{\text {ba }}$ & $248.8^{\mathrm{bcd}}$ & $298.8^{\mathrm{ba}}$ & $273.8^{\text {ba }}$ \\
\hline & KR & $4^{b}$ & $5^{\mathrm{a}}$ & $4.5^{\mathrm{a}}$ & $4^{b}$ & $5^{\mathrm{a}}$ & $4.5^{\mathrm{a}}$ & $263.8^{\mathrm{bc}}$ & $358.8^{\mathrm{a}}$ & $311.3^{\mathrm{a}}$ & $268.8^{\mathrm{bc}}$ & $363.8^{\mathrm{a}}$ & $316.3^{\mathrm{a}}$ \\
\hline & Mean GR & $4^{b}$ & $5^{\mathrm{a}}$ & - & $4^{b}$ & $5^{a}$ & - & $215.2^{b}$ & $307.5^{\mathrm{a}}$ & - & $219.8^{b}$ & $312.5^{a}$ & \\
\hline $\begin{array}{l}\text { GR=Growth } \\
\text { MC= Mepiqu } \\
\text { Ferti = fertiliz }\end{array}$ & $\begin{array}{l}\text { uat chloride } \\
\text { zer }\end{array}$ & & & & & & & & & & & & \\
\hline
\end{tabular}

Table 7. Effect of chemical potassium (KC), foliar potassium (KF), rock potassium (KR) and growth retardant (mepiquat chloride) applications on mean of potato tuber diameter $(\mathrm{mm})$ and mean of potato tuber size $(\mathrm{ml})$ during the two sampling dates in both seasons.

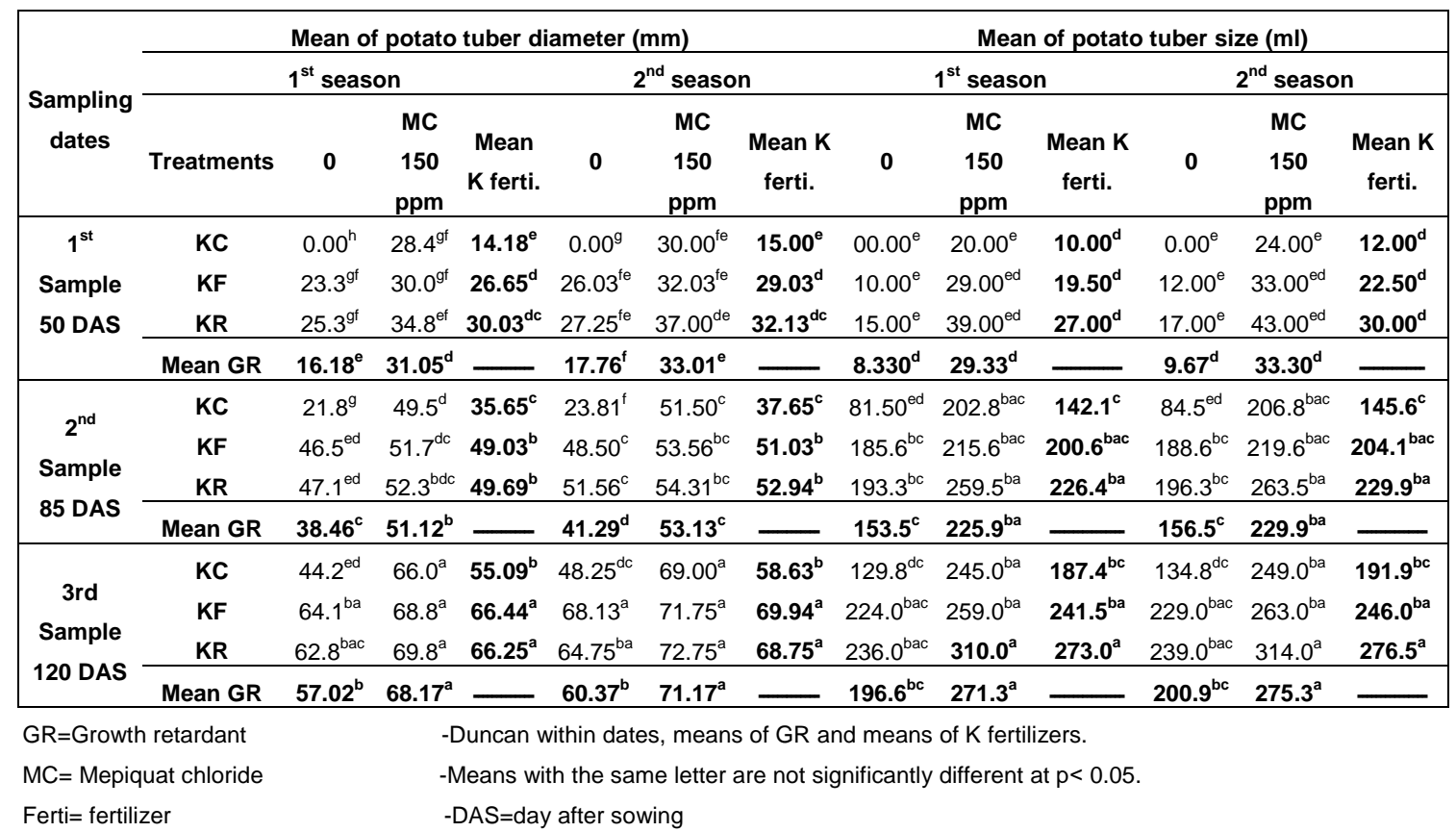


Rock potassium fertilization increased tubers size following by potassium foliar against the control (KC) and this increment between KF and KR reached the same level of significance in each sample after 85 and 120 days from sowing. Moreover, spraying of mepiquat chloride treatment obtained significant increment compared with without mepiquat chloride after 120 days from sowing. Obtained results on mepiquat chloride are agreeable with those reported by Hassan et al (1989) and Tsegaw et al (2005) on potato.

Results in Table (7) showed that the best combination treatment among rock potassium fertilization or potassium foliar with spraying of mepiquat chloride increased tubers size after 85 and 120 days from sowing in both seasons.

\section{Total tubers yield}

In respect to the application of potassium fertilizers effect, it is clear from Table (8) that the application of rock potassium fertilization produced the highest value on total tubers yield than the other potassium fertilizers. While, the same effect was obtained by the application of potassium chemical or potassium foliar after 120 days from sowing in both seasons. In addition to, spraying of mepiquat chloride recorded high production of potato yield compared with non-treatment plants after 120 days from sowing in two tested seasons. These results are in agreement with those obtained by Gasti et al (1997), Eyob \& Krishnappa (1999), Tavares and Lucchesi (1999), Bama et al (2001), Jayakumar et al (2001), Prakash et al (2001), Birbal and Kushwah (2003), Mahadevmurthy \& Nagarathna (2008) and Vyakarnahal et al (2010) who applied mepiquat chloride $\mathrm{MC}$ at $150 \mathrm{ppm}$ led to the highest yields in potatoes (33.29 t/ha), this represented yield increases $29.03 \%$, over the control.

As effect of the interaction, results in Table (8) indicated that the application of rock potassium combined with spraying of mepiquat chloride reflected the highest value of total tubers yield after 120 days from sowing in both seasons. However, the lowest value was obtained with the application of potassium chemical with without spraying of mepiquat chloride after 120 days from sowing in both seasons.

Table 8. Effect of three different sources of potassium (KC, KF\& KR) and growth retardant (MC) on total potato tubers yield (ton/fed) at harvesting stage in both seasons.

\begin{tabular}{|c|c|c|c|c|c|c|c|}
\hline \multirow{2}{*}{$\begin{array}{c}\text { Sampling } \\
\text { date }\end{array}$} & \multicolumn{4}{|c|}{$1^{\text {st }}$ season } & \multicolumn{3}{|c|}{$2^{\text {nd }}$ season } \\
\hline & Treatments & 0 & $\begin{array}{c}M C \\
150 \mathrm{ppm}\end{array}$ & Mean $\mathrm{K}$ ferti. & 0 & $\begin{array}{c}\text { MC } \\
150 \mathrm{ppm}\end{array}$ & Mean $\mathrm{K}$ ferti. \\
\hline \multirow{4}{*}{$\begin{array}{c}3^{\text {rd }} \\
\text { Sample } \\
120 \text { DAS }\end{array}$} & KC & $2.583^{b}$ & $5.049^{\mathrm{a}}$ & $3.8160^{b}$ & $2.679^{c}$ & $5.187^{\text {ba }}$ & $3.9330^{b}$ \\
\hline & KF & $4.558^{\mathrm{ba}}$ & $5.493^{\mathrm{a}}$ & $5.0255^{\mathrm{ba}}$ & $4.695^{b}$ & $5.623^{\mathrm{ba}}$ & $5.1590 \mathrm{~b}^{\mathrm{a}}$ \\
\hline & KR & $4.932^{\mathrm{a}}$ & $6.708^{\mathrm{a}}$ & $5.8200^{a}$ & $5.065^{\mathrm{ba}}$ & $6.839^{\mathrm{a}}$ & $5.9520^{\mathrm{a}}$ \\
\hline & Mean GR & $4.0243^{b}$ & $5.750^{\mathrm{a}}$ & 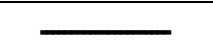 & $4.1463^{b}$ & $5.883 a$ & $\longrightarrow$ \\
\hline
\end{tabular}

GR=Growth retardants $\mathrm{MC}=$ Mepiquat chloride Ferti $=$ fertilizer
- Duncan within date, means of $\mathrm{GR}$ and means of $\mathrm{K}$ fertilizers.

- Means with the same letter are not significantly different at $p<0.05$.

- DAS=day after sowing

\section{CONCLUSION}

Rock potassium with mepiquat chloride obtained the highest productivity of fresh and dry weights, total tuber yield and tubers yield components (weight of tubers, size of tubers, diameter of tubers and number of tubers) following by foliar potassium with mepiquat chloride compared with control treatment.

\section{REFERENCES}

Abd El-Latif, K.M., Osman, E.A.M., Abdulla R. and Abdel Kader N., 2011. Response of potato plants to potassium fertilizer rates and soil moisture deficit. Advances in Applied Science Research, 2, 388-397.

Bama, K.S., Basker A. and Jayakumar, R. 2001. Influence of mepiquat chloride on total dry matter production, yield and nutrient uptake in po- 
tato. Madras Agricultural Journal, 87(10/12), 679-680.

Blagoeva, V., lliev E. and Nikolova, E. 2004. Potatoes-cultivation, diseases and pests, and storage. Publisher "Enjovche" Sofia. $105 p$.

Birbal, S.R.K. and Kushwah V.S. 2003. Effect of plant growth regulators on potato production. Journal of the Indian Potato Association, 30 (1/2), 195-196.

Brady, N.C. and Weil R.R. 2002. The Nature and Properties of Soil. $13^{\text {th }}$ Ed., Prentice Hall, Upper Saddle River, New Jersey, USA, pp. 143192.

Clark, R.U., Lovell, J.S., Thigpen, J.C., Bristol, D.W., Tyndall, J.R. and Frisbee, A.R., 1998. Mepiquat chloride. U.S. Patent No. 5,705,648. Washington, DC: U.S. Patent and Trademark Office

Daniel, E.K., Rosen C.J. and John A., 2014. Lamb: Extension Specialists in Nutrient Management. Potassium for Crop Production. University of minnesota extension. AGFO-3770-B.

Dean, B.B. 1994. Managing the Potato Production System. Food Products Press, USA, pp.59-61.

Duncan, D.B., 1955. Multiple range test and multiple $\mathrm{F}$ test. Biometrics, 11(1), 1-42.

Eyob, S. and Krishnappa, K.S. 1999. Effect of growth retardants on dry matter accumulation, starch and sugar content of potato grown from true potato seed (TPS). Karnataka Journal of Agricultural Sciences, 12(1/4), 243-245.

Gasti, V.D., Madalageri B.B., Dharmatti, P.R. and Ryagi Y.H., 1997. Studies on response of growth retardants on commercial vegetables. Advances in Agricultural Research in India, 7, 19-21.

Hassan, M.A.M., Farrag, M.M. and Farag, I.A. 1989. Response of potato cv. Diamant to various rates of mepiquat applied at three stages of plant growth. Assiut Journal of Agricultural Sciences, 20 (3), 143-157.

Havlin, J.L., Beaton J.D., Tisdale S.L. and Nelson W.L., 2005. Soil Fertility and Fertilizers:
A Introduction to Nutrient Management. $7^{\text {th }}$ Ed., Pearson Educational, Inc., Upper Saddle River, New Jersey, USA, 97-141.

Jackson, S.D., 1999. Multiple signalling pathways control tuber induction in potato. Plant Physiol., 119, 1-8.

Jayakumar, R., Sathiyabama K. and Ravikumar V., 2001. Influence of mepiquat chloride on bio efficacy and quality parameters of potato (Solanum tuberosum L.). Research on Crops, 2(3), 368-371.

Mahadevmurthy, M. and Nagarathna, T.K. 2008. Effect of chamatkar on yield of potato. Mysore Journal of Agricultural Sciences, 42 (1), 170171.

Prakash, P.; Chetti M.B. and Nalini A.S., 1999. Effect of plant growth regulators on morphological traits and their relationship with yield in TPS and tuber propagated potato. South Indian Horticulture, 47(1/6), 259-261.

Prakash, P.; Chetti M.B. and Patil S.S., 2001. Effect of plant growth regulators on growth parameters and yield in potato. Karnataka Journal of Agricultural Sciences, 14(4), 938-942.

Steel, R.G.D. and Torrie, J.H., 1960. Principles and Procedures of Statistics. $1^{\text {st }}$ Ed., McGraw Hill, New York, USA, pp. 107-109.

Tavares, S. and Lucchesi A.A., 1999. Plant regulators in potatoes $\mathrm{cv}$. Monalisa after tuberization. [Portuguese]. Scientia Agricola, 56(4), 975-980.

Tsegaw, T., Hammes P.S. and Robbertse J. 2005. Paclobutrazol-induced leaf, stem, and root anatomical modifications in potato. HortScience, 40 (5), 1343-1346.

Vyakarnahal, V.K., Basavaraj B.S. and Birbal N. 2010. Effect of growth retardants and methods of application on growth and yield of potato. Indian Journal of Horticulture, 67, Special Issue, 308-313.

White, P.J., Broadley M.R., Hammond J.P. and Thompson A.J., 2005. Optimising the potato root system for phosphorus and water acquisition in low-input growing systems. Aspects App. Biol., 73,111-118. 


\section{على سعيد محمد حسن أبوالنجا

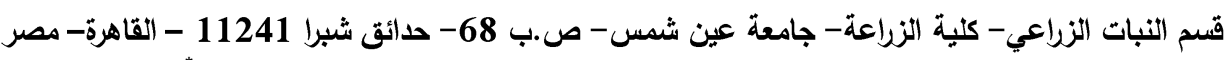

"Corresponding author: aliaboalnagaa1984@gmail.com

Received 21 October, 2018, $\quad$ Accepted 25 October , 2018

البوتاسيوم الكيميائي (الكنترول) مع /بدون مبيكوات

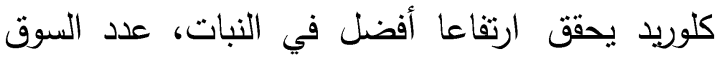

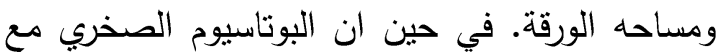

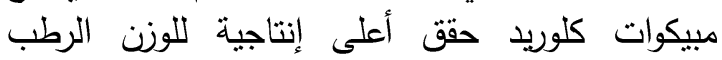

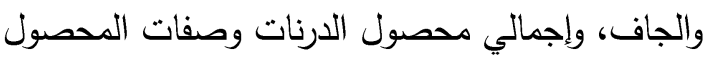

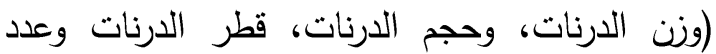

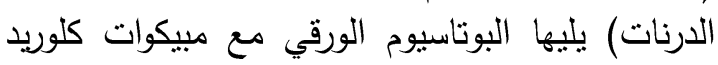

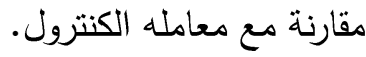

الكلمات الدالة: نبات البطاطس، البوتاسيوم الصخري،

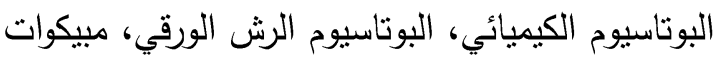

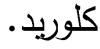

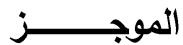

في هذه الدراسة تم إجراء تجربتين ميدانيتين في

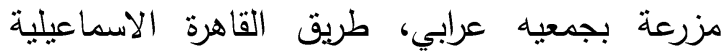
الصحراوي بمحافظة القليوبية .أجريت التجربة خلال موسمي 2014/2013 و و2016/2015، لدراسة تأثنير منظم نمو النبات مبيكوات كلوريد مع ثلاثة مصادر مختلفة لأسمدة البوتاسيوم [البوتاسيوم الكيميائي (KC) البوتاسيوم الورقي (KF) وصخور البوتاسيوم(KR)] على النمو والتطور والإنتاج الكلي في نباتات البطاطس (Solanum tuberosum L. cv. Spunta). 